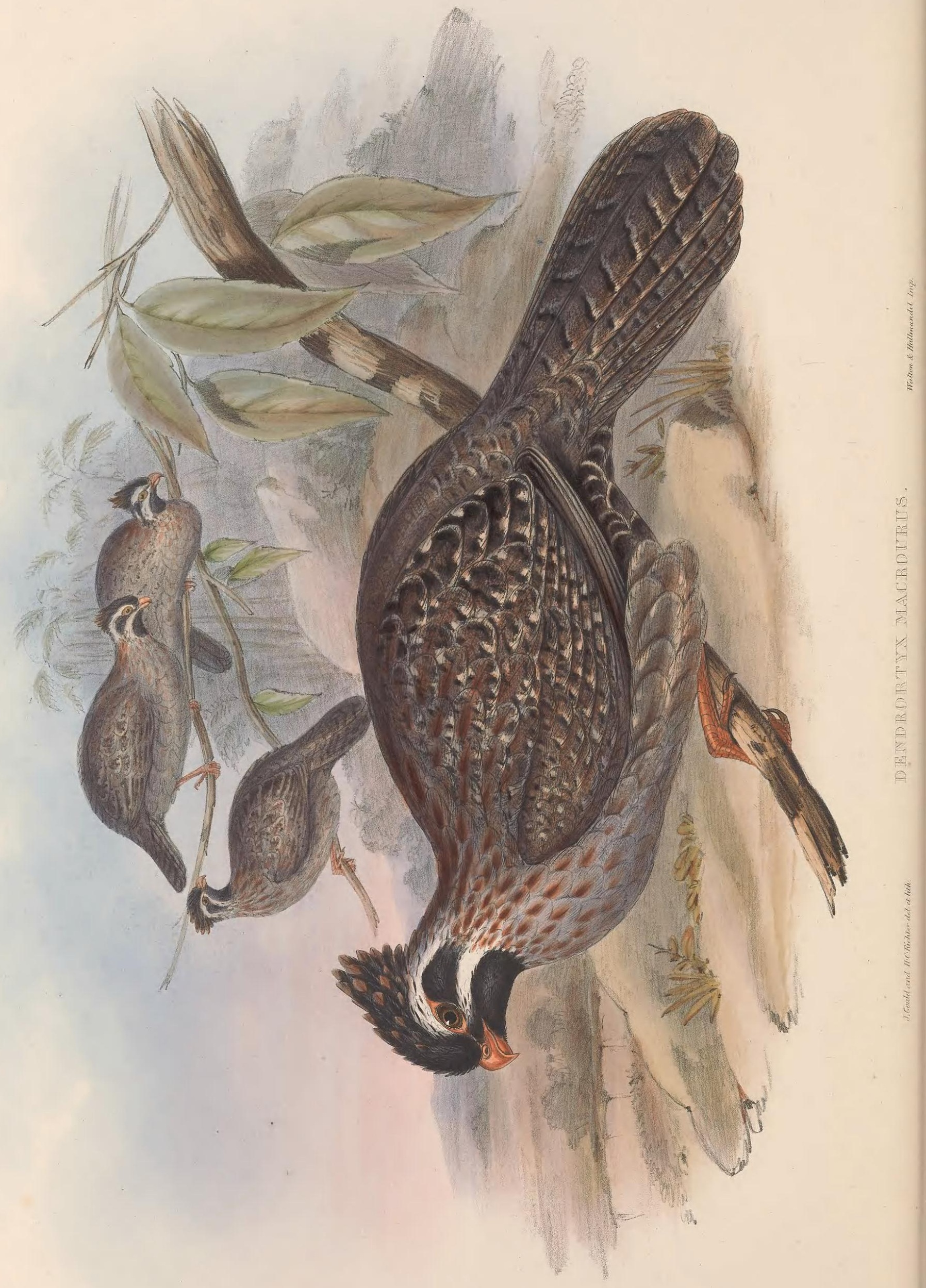




\title{
DENDRORTYX MACROURUS.
}

\section{Large-tailed Partridge.}

\author{
Specific Character.
}

Dend. fronte et gulâ nigris; lineâ albâ super, atque infra plumas auriculares.

Head crested, the feathers inclining backwards; forehead, throat, ear-coverts and crest black, the feathers of the latter with a spatulate spot of reddish brown at the extremity; two lines, one above and the other below the ear-coverts, white; upper part of the chest, back of the neck and mantle rich chestnut-red, the edges of the feathers being grey; all the upper surface, wings and tail olive-brown, assuming the form of transverse bars on the wings and tail ; primaries uniform greyish brown; under surface grey, each feather with a line of chestnut down the centre, and indistinct markings of greyish white on the margins of the webs; under tail-coverts black edged with buff; bill, feet and orbits red.

Total length, $15_{\frac{1}{2}}$ inches; bill, $\frac{\frac{s}{4}}{4}$; wings, $6_{\frac{1}{2}} ;$ tail, $6_{\frac{1}{2}}$; tarsi, $2 \frac{1}{\frac{1}{2}}$; middle toe and nail, 2 .

Ortyx macroura, Jard. and Selb. Ill. Orn., vol. i. pl. 49.-Nat. Lib. Orn., vol. iv. pl. 12.

THIs species, the largest of the family yet discovered, is a native of Mexico, and is so rare in the cabinets of this country, that the specimen in the collection of Sir William Jardine, Bart., is the only one I am acquainted with; it was purchased at the sale of Bullock's London Museum. Another example, which has been kindly lent me to figure from, is contained in the collection of Prince Massena at Paris; the colouring of these two specimens is precisely alike, and they appear to be adult males.

The late M. Natterer considered this bird to be identical with the Tetrao nevius of Gmelin; but upon comparing the abơve-mentioned specimens with his description, I find so great a disparity between them, that though he may be correct in this opinion, still, as the details given are vague and indefinite, I should deem it hazardous to adopt Gmelin's specific name. He states, for instance, that the $T$. ncevius is twentyone inches long, whereas the present bird does not exceed sixteen inches; and he mentions nothing respecting the black colouring of the head and throat; I have therefore retained for it Messrs. Jardine and Selby's appropriate appellation of macrourus.

Of the habits and economy of this species I regret to say nothing whatever is known.

Habitat, Mexico.

The Plate represents an adult male of the natural size. 


\section{$2 \mathrm{BHL}$ Biodiversity Heritage Library}

Gould, John. 1850. "Large-tailed Partridge, Dendrortyx macrourus [PI. XX]." A monograph of the Odontophorince, or, Partridges of America -. https://doi.org/10.5962/p.323680.

View This Item Online: https://www.biodiversitylibrary.org/item/250453

DOI: https://doi.org/10.5962/p.323680

Permalink: https://www.biodiversitylibrary.org/partpdf/323680

\section{Holding Institution}

Smithsonian Libraries

\section{Sponsored by}

Biodiversity Heritage Library

\section{Copyright \& Reuse}

Copyright Status: Public domain. The BHL considers that this work is no longer under copyright protection.

This document was created from content at the Biodiversity Heritage Library, the world's largest open access digital library for biodiversity literature and archives. Visit BHL at https://www.biodiversitylibrary.org. 